\title{
UPAYA PEMBENTUKAN AKHLAK PESERTA DIDIK DENGAN MODEL PEMBELAJARAN BANDONGAN
}

\author{
Dedi Wahyudi \\ Institut Agama Islam Negeri Metro \\ Jl. Ki Hajar Dewantara Kampus 15A Iringmulyo Kota Metro Lampung 34111 \\ e-mail: podoluhur91@gmail.com \\ Rani Hidayaturohmah \\ Institut Agama Islam Negeri Metro \\ Jl. Ki Hajar Dewantara Kampus 15A Iringmulyo Kota Metro Lampung 34111 \\ e-mail: rhanihr95@gmail.com
}

\begin{abstract}
Abstrak
This paper is based on the problems of students, especially at the level of elementary education that follows the learning process of the bandongan model. Bandongan is a method using a circular sitting system with the teacher around the students, and still uses a very classic traditional method in his time. This article was made because of the many well-known and varied learning models, but it still did not last long in the current era. The purpose of this paper is to strive for the formation of the morality of students so that they are better and can be a reference point in teaching morality subjects. The method of taking this learning model is by literature study and field study.
\end{abstract}

Keywords: the building of morals, learning, bandongan

\begin{abstract}
Abstrak
Tulisan ini didasari dengan permasalahan peserta didik khususnya di tingkat pendidikan dasar yang mengikuti proses pembelajaran model bandongan. Bandongan yaitu sebagaimana sudah diketahui bahwa metode ini menggunakan sebuah sistem duduk melingkar dengan guru berada di sekeliling peserta didik, dan masih menggunkan cara tradisional yang sangat klasik pada zamannya. Tulisan ini dibuat karena banyaknya dikenalnya model pembelajaran yang begitu banyak dan variatif, akan tetapi masih kurang bertahan lama pada era saat ini. Tujuan penulisan ini adalah untuk mengupayakan proses pembentukan akhlak peserta didik agar lebih baik dan dapat menjadi titik acuan dalam mengajarkan mata pelajaran akidah akhlak. Metode pengambilan model pembelajaran ini yakni dengan studi pustaka dan juga studi lapangan.
\end{abstract}

Kata kunci: pembentukan akhlak, pembelajaran, bandongan 


\section{Pendahuluan}

Kegiatan pembelajaran akan menjadi hal yang paling penting dalam proses pembelajaran dan menjadikan titik keberhasilan seorang guru adalah pada proses belajar mengajarnya di dalam kelas. Dalam kegiatan pembelajaran akan memprioritaskan keaktifan siswa dalam merespon apa yang telah guru sampaikan. Oleh karenanya, hal ini menjadi suatu yang membuat kegundahan hati para guru saat akan menyampaikan materi. Karena mereka dituntut untuk mendesain proses pembelajaran agar bisa menarik dan peserta didik agar terkondisikan dengan baik dan keaktifan mereka menjadi prioritas utama. ${ }^{1}$

Sebagai seorang pendidik, keberhasilan belajar ada ditangan mereka dan pendidik menjadi figur sentral dalam pembentukanakhlak pesertadidik. ${ }^{2}$ Ditangan para pendidiklah kesuksesan belajar akan tercapat. Hal itu disebabkan karena mengajar dan mendidik peserta didik merupakan tugas utama pendidik setelah orang tua, ini menjadiamanah besar dan tugas paling serius bagi mereka para pendidik. Terutama dalam mata pelajaran pendidikan agama Islam. Hal mendidik menjadi tugas paling serius karena menyangkut tentang proses belajar agama dan proses mengajarkan kepada mereka kebaikan-kebaikan yang disukai Allah SWT. Pendidik juga merupakan sebagai pemegang kesempatan untuk memperbaiki generasi penerus bangsa.

Dalam tulisan ini akan dibahas permasalahan proses belajar yang membutuhkan banyak model pembelajaran agar peserta didik mampu menyerap materi dengan baik. Penulis menemukan

${ }^{1}$ Tri Yuniarti and Syamsu Hadi, "Peningkatan Kemampuan Analisis Pokok Bahasan Masalah Ekonomi Dengan Model Pembelajaran Problem Based Learning (PBL) Siswa SMA Negeri 1 Bandongan Kabupaten Magelang," Dinamika Pendidikan 10, no. 1 (2015): 76-87. Mengajar. model pembelajaran bandongan yang biasa digunakan oleh seorang ustadz untuk membimbing santrinya, agar mampu membaca kitab dengan baik dan benar. $^{3}$ Dimaksudkan dalam penulisan ini natinya akan lebih kedalam proses pembentukkan akhlak mahmudah dengan cara pendekatan atau model pembelajaran bandongan. Karena proses pembentukan akhlak tidak bisa efektif jika diteorikan saja, akan tetapi harus ada pendekatan yang lebih masif, agar peserta didik lebih terdeteksi apa yang ia inginkan sebenarnya. Model pembelajaran ini dilakukan untuk menajadikan peserta didik menjadi lebih tertata akhlaknya dan dakwah fardiyahnya akan lebih baik.

Model pembelajaran bandongan seperti ini biasanya banyakditerapkan di pondok pesantren, yang mana pada proses ini peserta didik atau santri duduk melingkari guru ataupun ustadznya, untuk siap menerima materi ataupun menyetor hafalan kitab atau mengartikan kitab. Bandongan bisa disebut juga sebagai bentuk proses halaqoh dan pertama kali model pembelajaran ini dilakukan di sekitar jawa. Karena pada masa itu, banyak yang berguru langsung pada sang empunya ilmu yang lebih tinggi dari yang lain. ${ }^{4}$ Dengan begitu proses penjelasan tentang keilmuan lebih intens jika dilakukan dengan model ini, karena langsung berhadapan dengan guru atau ustadz. Begitupun proses penerimaan materi akan lebih efektif tersimak karena jarak antara guru dan peserta didik lumayan dekat.

Kegiatan pembelajaran haruslah selalu divariasikan dengan sebuah metode yang tidak membuat peserta didiknya merasa jenuh dan bosan. Pendekatan pada

${ }^{3}$ Lembaga Studi Islam et al., Sejarah Pendidikan Islam Di Indonesia: Lintasan Sejarah Pertumbuhan Dan Perkembangan.

4 "Zamakhsyari Dhofier, Tradisi Pesantren: Studi Pandangan Hidup Kyai Dan Visinya Mengenai Masa Depan Indonesia, Jakarta : LP3ES, Cet. 9, Hlm. 54.," Jakarta : LP3ES. cet. 9, hlm. 54. (n.d.). 
peserta didik harus benar-benar maksimal dilakukan agar peserta didik fokus terhadap apa yang disampaikan oleh seorang guru. Pembentukkan akhlak dengan model ini bisa dilakukan secara santai, dan bisa dilakukan dengan diskusi atau sambil berbincangbincang setelah melakukan pembelajaran. Hal ini dilakukan agar pendekatan kepada hati peserta didik lebih mudah dijangkau, sehingganya dari sedikitnya percakapan atau perbincangan yang dilakukan guru dan peserta didik akan terlihat bagaimana sikap sebenarnya peserta didiknya itu.

Proses yang dijadikan model pembelajaran ini, akan lebih efektif dalam memproses peserta didik terutama dalam bidang studi Akidah Akhlak. Karena pembentukan akhlak mencakup dari tingkah laku, spiritual, jasmaniyah, rohaniah, intelektualitas dan interaksi sosialnya. ${ }^{5}$ Setiap daerah dan juga tempat pendidikan akan memiliki sebuah sejarah yang mana itu akan menjadi kebiasaan yang akan diterapkan dalam sebuah pembelajaran, sama halnya dengan model bandongan ini, dikenal dengan sistem halaqoh, yang mana dulu bandongan ada karena sejarah dari para guru zaman dulu, terutama di pesantren yang masih kental dalam menggunakan model bandongan. ${ }^{6}$

Pembelajaran ini merupakan metode paling utama dalam sistem pembelajaran di pesantren. Dalam sistem ini, menggunakan sekelompok peserta didik atau santri antara 5 sampai ratusan orang, yang mana mereka mendengarkan guru menjelaskan, membaca sambil menerjemahkan dan menerangkan mata pelajaran yang diampu guru ataupun ustadz tersebut. Setiap dari mereka, memperhatikan dan mencatat apa yang

${ }^{5}$ Muhammad Addib Zubaidi and others, 'Sistem Pendidikan Dakwah Pondok Pesantren Nurul Haromain Pujon Malang Dan Perkembangannya (Skripsi, Universitas Negeri Malang Fakultas Ilmu Sosial, Malang, 2012), http://jurnal-online.um.ac.id/data/ artikel/artikel7E1416A3E9F21E892782EA3215B47D8D. pdf. mereka dengar dan menulis sesuai yang mereka fahami. ${ }^{7}$

Model bandongan sangat pas jika digunakan di lingkup pesantren karena di banyak lembaga pendidikan formal akan kurang cocok jika menggunakan metode ini, dan juga akan terlihat membosankan jika digunakandierasaatini.Karenasecarabahasa Bandongan berarti pengajaran dalam bentuk kelas di suatu lembaga Agama, pesantren atau sekolah yang berbasis agama.Sedangkan tujuannya dari masih diberlakukannya model pembelajaran bandongan adalah agar peserta didik lebih fokus dalam membaca buku sekaligus dapat menghafal ilmu yang ada di dalam buku tersebut, dan menyimak apa yang sedang dijelaskan oleh guru atau ustadz masing- masing.

Dengan menggunakan model ini, sangat diharapkan penyampaian materi akidah akhlak dan sekaligus pembentukkannya akan menjadi lebih efektif. Karena materi akhlak sangat mudah dan fleksibel untuk menggunakan model pembelajaran seperti apa. Dengan model bandongan, bisa diselipkan dengan menontonkan sebuah video bagaimana harus berakhlak mahmudah yang baik menurut pandagan syara'. Kemudian dari hal itu, pendidik bisa menuntun mereka untuk menerapkan dari materi akhlak mahmudah yang sudah dipelajari bersama dengan model pembelajaran bandongan tersebut.

\section{Metode Penelitian}

Penelitian ini di ambil dengan menggunakan sebuah pendekatan sosiologis dengan metode yang digunakan adalah metode penelitian kualitatif dan dengan jenis penelitian studi pustaka dan lapangan. Pendekatan tersebut diatas menggambarkan tentang subjek yang diteliti itu melakukan sebuah interaksi di dalam pembelajaran.

7 "Zamakhsyari Dhofier, Tradisi Pesantren: Studi Pandangan Hidup Kyai Dan Visinya Mengenai Masa Depan Indonesia, Jakarta : LP3ES, Cet. 9, Hlm. 54.pdf." 
Penelitian kualitatif digunakan karena penelitian ini menggunakan sebuah latar belakang, dengan maksud mentafsirkan sebuah kejadia atau fenomena yang sedang terjadi dan kemudian mengikutsertakan metode pembelajaran yang diambil. ${ }^{8}$

\section{Pembentukan Akhlak Mahmudah}

1. Pengertian Pembentukan

Pembentukan mencakup segala bentuk dan masih sangat umum, sebagai pembentukan apa dan dan ditujukan pada siapa. Digunakan dalam peristiwa ataupun keadaan apapun, pembentukan merupakan sebuah tindakan dan juga proses yang akan dilakukan dan akan menghasilkan sesuatu yang akan menjadi tujuan dilakukannya kegiatan tersebut. Berdasarkan definisi yang didapat, pembentukan adalah suatu proses melakukan perubahan pada sesuatu dengan melakukan tindakan-tindakan yang akan mendukung proses tersebut.

Proses pembentukan dilakukanharus berdasarkan asumsi yang benar-benar akan menimbulkan efek perubahan, kemajuan, peningkatan, dan juga pertumbuhan serta perkembangan yang menjadi tujuan utama dari diadakannya suatu pembentukan tersebut. ${ }^{9}$ Pembentukan juga bisa disebutkan sebagai proses penanaman dan pembelajaran untuk diarahkan pada sesuatu yang lebih baik dan memiliki sebuah tujuan yang lebih logis dan mengakibatkan adanya perubahan dari situasi sebelumnya dan sesudahnya. Setelah dilakukannya suatu pembentukan tidak lepas dan selesai begitu saja, akan tetapi akan diadakannya lagi sebuah penanaman, pendekatan, dan pembinaan secara urut, guna menyempurnakan apa yang akan menjadi tujuan utama.

${ }^{8}$ Zubaidi and others, 'Sistem Pendidikan Dakwah Pondok Pesantren Nurul Haromain Pujon Malang Dan Perkembangannya.

${ }^{9}$ Puji Rahayu, "Peran Dakwah Muslimat Nahdlatul Ulama Dalam Pembinaan Akhlak Warga Desa Bendar Kecamatan Juwana Kabupaten Pati" (IAIN Walisongo, 2013), http://eprints.walisongo.ac.id/1920/.
2. Pengertian Akhlak Mahmudah

Mata Pelajaran Pendidikan Agama Islam di tingkat pendidikan dasarnya khususnya mdarasah merupakan mata pelajaran penting yang harus dimajukan untuk menjadikan peserta didik menjadi lebih paham mengenai agama, dan juga apa yang akan dilakukan dan didapatkan dari apa yang dipelajari..$^{10}$ Dalam mata pelajaran pendidikan agama Islam tidak hanya soal ibadah yang akan di pelajari, akan tetapi mengenai akhlak dan tingkah laku akan dibahas dengan baik, guna mengubah dan memperbaiki akhlak peserta didik agar menjadi lebih baik dan bisa menjadi kebanggaan keluarga dan juga masyarakat. Peserta didik juga akan dijelaskan mengenai akhlak yang baik dan juga akhlak yang buruk.

Akhlak sendiri diartikan sebagai bentuk tingkahlaku, sifat, gerakan,adat, tabiat dan sebagainya. Jika diistilahkan bahwa akhlak itu sendiri merupakan sesuatu yang dilakukan dengan suatu keinginan untuk bertemu, dan itu akan terjadi secara sadar. Akhlak yang baik (mahmudah) merupakan akhlak yang terpuji, dan apabila dilakukan tidak akan menimbulkan bahaya, dan juga didalam hatinya ada sebuah ketulusan dan sudah sesuai dengan syara'. ${ }^{11}$ Selain itu juga, akhlak mahmudah sudah dipastikan akan menjadi akhlak yang terpuji. Akhlak mahmudah biasanya akan dihiasi dengan sebuah kelembutan hati, kejujuran, kebenaran, sikap berani dan juga dapat dipercaya dan sikap-sikap terpuji lainnya. Dan yang biasa menyandang semua sifat itu hanya para Nabi dan Rasul,

${ }^{10}$ Haryanto Haryanto, "Upaya Meningkatkan Etika Pergaulan Siswa Dengan Metode Demontrasi Mata Pelajaran Aqidah Akhlak Materi Akhlak Mahmudah Kelas IV Semester I Di MI Karangwotan Pucakwangi Pati Tahun Periode 2010-2011" (IAIN Walisongo, 2011).

${ }^{11}$ Imroatul Latif Nikmaturrohmah, "Pembiasaan Shalat Dhuha Dalam Pembinaan Akhlak Peserta Didik Di MTs Al-Ghozali Panjerejo Rejotangan Tulungagung" (2014). 
jarang dimiliki oleh manusia biasa kecuali memang dia menerapkan pada diri mereka. Walaupun kita tidak bisa sepenuhnya menerapkan semua sifat terpuji yang Nabi dan Rasul miliki, akan tetapi kita masih bisa menerapkan yang mampu kita terapkan. Seperti halnya melakukan kema'rufan yang akan menjadi benteng dari hal-hal yang akan membuat kita terlena akan melakukan kemunkaran. Karena sesungguhnya syeitan tidak akan membiarkan manusia untuk hidup tenang dalam syariat, maka segala bentuk bisikan-bisikan akan terus di berikan kepada manusia yang tidak berpegang teguh kepada Allah. ${ }^{12}$

Akhlak terpuji atau akhlak mahmudah merupakan aplikasi dari tanda keimanan seseorang, yang mana apabila keimanan seseorang. Dari sebuah keimanan yang dimiliki seseorang dan juga peserta didik akan tampak dari cerminan iman itu, sebuah akhlak yang terpuji. Jadi, bisa dikatakan jika seseorang tidak tertanam iman dalam hatinya, maka akan tampak apa yang dilakukannya tidak tampak suatu cerminan dari iman itu, akhlak yang akan terlihat yakni sebuah akhlak tercela yang akan merugikan dirinya sendiri dan akan berdampak pada hubungannya dengan yang lain. ${ }^{13}$ Begitupun nikmat iman akan tercermin dari perilaku terpuji seseorang, dari caranya bersosialisasi dengan yang lain, pun hubungannya dengan Allah terasa sangat baik.

Untuk menerapkan akhlak mahmudah dalam diri kita, sebelumnya haruslah kita mengetahui dulu kepada siapa saja kita berakhlak baik, yakni kepada Allah Subhanahu wa Ta'ala, kepada sesama manusia, dan kepada makhluk hidup lain serta alam semesta. Karena akhlak itu sendiri akan bersangkutan dengan kecerdasan dan juga emosional pada diri masing-

\footnotetext{
12 Ibid.

13 Andi PramudyaPembagian Akhlak Dalam Islam, ((http://konsep-islam.blogspot.com/2011/10/ pembagian-akhlak-dalam-islam.html), 2011).
}

masing individu. ${ }^{14}$ Dari yang telah diteliti, kecerdasan bersangkutan dengan akhlak karena, orang yang tahu mereka harus berbuat baik dengan sesama, makhluk dan alam tidak akan bisa dilakukan dengan oleh orang yang tidak cerdas, dikarenakan ia tidak bisa membedakan mana yang baik dan yang buruk, dan dengan begitu semua tidak bisa dilakukan tanpa dasar yakni pengetahuan. Begitupun dengan emosional, karena sabar membutuhkan sebuah kelembutan hati, untuk menahan dari setiap apa yang akan membuatnya menggunakan perasaannya.

Akhlak yang kita terapkan dalam diri kita, merupakan salah satu pondasi dasar yang harus dimiliki seseorang, yakni akidah, syariah dan akhlak. Penerapan dari syariah dan akidah akan menghasilkan akhlak yang sudah teralisasi dengan segala pengetahuanpengetahuan y6ang telah didapat, dan akhlak tidak akan terbentuk secara spontan dalam diri jika seseorang tidak memiliki akidah dan syariah yang baik. ${ }^{15}$ Penerapan dan pembentukan akhlak biasanya akan lebih tercapai disuatu lembaga yang berada dibawah Kemenag (Kementrian Agama) yang mana pada lembaga ini akan lebih mengutamakan sebuah tujuan pada karakter Islam yang lebih dari yang akan di capai dari lembaga lain.

Pada lembaga jenjang pendidikan Madrasah, seperti Madrasah Ibtidaiyah penerapan akan lebih baik dan menjadi tujuan utama bagi mereka. Karena, mata pelajaran agama tidak hanya sebagai formalitas semata, tetapi menjadi mata pelajaran pokok pada lembaga tersebut. Dalam lembaga Islam, mata pelajarannya bukan sekedar Pendidikan Agama Islam saja, tetapi terdapat banyak unsur-unsur didalamnya, seperti akidah akhlak,

${ }^{14}$ M. A. Djazimi, "Pengaruh Kecerdasan Emosional Terhadap Akhlak Siswa Madrasah Aliyah Alkhairiyah Provinsi Banten," StudiaDidaktika 10, no. 02 (2017): 48-64.

15 Marzuki, Prinsip Dasar Akhlak Mulia, (Yogyakarta, Debut Wahana Pers, 2009).pdf. 
sejarah kebudayaan Islam, fiqh dan lain sebagainya. Dari segi penelitian yang lebih menunjang tentang pembelajaran agama islam adalah penerapan akhlak yaitu pada mata pelajaran akidah akhlak. Dikarenakan standar kompetensi kelulusan pada mata pelajaran akidah akhlak pada lembaga madrasah yakni menumbuh kembangkan akidah melalui pemberian, pemupukan, dan pengembangan penegtahuan, penghayatan, pengalaman, serta pengalaman peserta didik tentang akidah Islam itu sendiri, sehingga akan menjadi manusia yang akan terus berkembang iman dan juga takwanya kepada Allah SWT. Adapun tujuannya diadakan adanya mata pelajaran akhlak itu sendiri adalah untuk mengurangi dan menghindari perbuatan dan juga sikap tercela yang sangat rentan terjadi yang akan menjadi kebiasaan anak-anak di lingkup sosial yang semakin rusak moral dan adabnya. Oleh karena itu, lembaga sekolah haruslah menjadi suatu pilihan yang diprioritaskan dalam memilihkan sekolah untuk anak, karena akan menjadi titik perubahan dimana anak tersebut dididik. ${ }^{16}$

Akhlak seseorang terutama peserta didik dipengaruhi oleh beberapa faktor, yakni faktor eksternal dan juga faktor internal. Diantaranya faktor eksternal akan mempengaruhi akhlak seseorang atau peserta didik yakni dari segi lingkungan, sekolah dan pergaulan sosilanya dengan masyarakat. Sedangkan dari faktor internal yakni, bisa melalui keluarga yang mendidiknya di rumah, dan memberikan contoh tentang bagaimana bersikap yang baik dan akan menghasilkan akhlak yang baik dan juga dari dalam diri seseorang atau peserta didik itu sendiri yakni dari segi kecerdasan dan emosionalnya. ${ }^{17}$ Imam Al-

${ }^{16}$ Lampiran Peraturan Menteri Agama Republik Indonesia Nomor 2 Tahun 2008 Tentang Standar Kompetensi Lulusan Dan Standar Isi Pendidikan Agama Islam., n.d., http://sutardicool.files.wordpress.com/2013/02/ permenag-no-8-tahun-2008-ttg-standar-isi-ktsp.pdf.

17 Djazimi, "Pengaruh Kecerdasan Emosional Terhadap Akhlak Siswa Madrasah Aliyah Al-Khairiyah
Ghazali mendefinisikan akhlak merupakan suatu sifat yang telah mengakar dalam jiwa dan telah tertanam dari sejak ia dilahirkan, yang mana dari dalam dirinya lahir berbagai perbuatan yang akan menjadikan ciri khas dari setiap individu itu sendiri. Dan dari sikap itu sendiri akan lahirlah sebuah perbuatan yang baik dan terpuji dari segi akal dan syara' ataupun malah sebaliknya yakni menjadikan lahirnya perbuatan tercela yang jauh dari tuntunan syara' ${ }^{18}$

Baru-baru ini begitu banyak pemberitaan mengenai pelanggaran norma yang terjadi banyak dikalangan remaja, dan juga anak sekolah yang pembentukkan akhlaknya tidak sampai pada mereka. Hal ini bisa disebabkan oleh banyak faktor yang sudah dituliskan diatas, dan pemberitaan tidak henti-hentinya tersebar di media, baik cetakmaupunonline.Pemberitaanitumenjadi PR tersendiri bagi lembaga pendidikan, tenaga pendidik, dan terutama orang tua, yang mana menjadi peran pembentuk bagi generasi penerus. Semua itu menjadi sebuah momok dan tugas besar bagi semua, karena akibat segala bentuk contoh perbuatan tidak baik sudah tergambar jelas dan sangat viral tersebar diseluruh pelosok media. Dari menggunakan narkoba, tawuran, minuman bebas, sex bebas, dan masih banyak lagi. Hal ini harus ditindak lanjuti bagi yang berwajib, karena akan berakibat merusak generasi muda yang masih dalam tahap mencari jati diri yang itu akan menjadi penentu masa depan mereka. Bagaimanajadinya jika semua menjadi bungkam terhadap masalah yang sudah sangat jelas akan menjadi pembobrok apa yang sudah dibangun dengan segenap usaha dan doa. ${ }^{19}$

Dari segenap permasalahan yang telah menjadi hantu bagi para pendidik, akan menjadi tugas terberat untuk

\footnotetext{
Provinsi Banten."

${ }^{18}$ Al-Ghazali, Ihya Ulumuddin,, n.d.pdf.

${ }^{19}$ Nurseri Hasnah Nasution, "Metode Dakwah Dalam Membentuk Akhlak Mahmudah Remaja," Wardah 12, no. 2 (2015): 163-177.
} 
memperbaiki mereka, yang telah atau yang belum tersentuh dengan sesuatu yang akan menjadi pengahancur itu. Sebenarnya, hal ini sudah pernah terjadi saat dimana moral tak ada harganya, dan semua tidak ada nilainya, yakni pada zaman Rasulullah Shalallahu a'alihi wa sallam. Sebelum masuknya islam, dan pada saat islam belum dilaksanakan dengan baik oleh penduduk arab waktu itu. Mereka benar-benar dalam masa jahil, tidak mengetahui apapun dan apapun yang mereka lakukan sangat jauh dari kata baik dan sangat melanggar norma-norma kehidupan.

Dalam membentuk akhlak haruslah banyak menggunakan metode yang paling ampuh dan menyesuaikan dengan keadaan. Di era yang semakin minim moral seperti saat ini, haruslah kita sebagai pendidik untuk mengajak mereka menelusuri berbagai sejarah dan juga bentuk akhlak yang baik untuk dijadikan sebagai tolak ukur dan juga kisah yang harus banyak diketahui agar mereka merasa tersentuh hati untuk melakukan perubahan. Seperti halnya, yang harusnya dilakukan seorang pendidik adalah dengan banyak memeberi pengetahuan tentang kisah Nabi dan Rasul serta sahabat-sahabat yang memiliki perangai yang baik. Karena telah disebutkan dalam sebuah hadits bahwa dari Malik telah sampai kepadanya bahwa Rasulullah Shalallahu a'alaihi wa sallam, bersabda yang artinya"Aku diutus untuk menyempurnakan akhlak yang baik" (HR. Malik) $)^{20}$

Di dalam Al Qur'an banyak dijelaskan bagaimana untuk membina dan membentuk akhlak dalam agama islam yang diajarkan dengan syara' yakni ada dalam QS. Al Qolam: 4 dan QS. Al Ahzab: 21. Ayat yang telah dicantumkan dalam dua surat yang berbeda diatas mempunyai dua inti yang sama yakni sebagaimana dinyatakan bahwa, Nabi Muhammad SAW

${ }^{20}$ Ibid. merupakan seseorang yang patut dijadikan panutan dalam kehidupan, dari caranya bergaul, bertingkah laku, bersosialisasi dengan masyarakat keluarga sanak saudara, karena di dalam dirinya sudah tertanam suri tauladan yang baik. ${ }^{21}$

Dapat ditengok kebelakang, masa dimana dizaman Rasulullah yang sudah disinggung diatas mengenai akhlak di zaman dahulu yang sekarang mulai tergambar lagi. Dimana para anak muda yang masih berstatus pelajar dan juga peserta didik tidak enggan memamerkan trendnya yang kekinian, dengan kebejatan moral yang malah semakin menjadi-jadi ditiru untuk menjadikan diri lebih dikatakan gaul. Lalu, bagaimana cara agar peserta didik tidak terjerumus pada sebuah ketercelaan pergaulan yang sudah marak terjadi saat ini? Maka dengan diadakannya model pembelajaran ini ditujukan untuk melakukan sebuah pendekatan yang lebih lagi untuk membina mereka sekaligus membentuk karakter dan juga akhlak mereka agar tidak salah mengarah dan ini akan dijadikan salah satu alasan untuk menyelamatkan generasi muda yang akan menjadi penerus kita.

Persoalan akhlak tidak akan selesai begitu saja, mulai dari kalangan orang dewasa hingga anak-anak, telah terjadi kemerosotan. Anak-anak diakibatkan dari orang tua mereka yang tidak mengarahkan untuk berpribadi islami, tidak mneyekolahkan mereka di madrasah, dan membiarkan mereka untuk bergaul dengan siapapun tanpa pandang kondisinya. ${ }^{22}$ Dalam konsep kebahasaan antara etika, moral dan akhlak mempunyai kemiripan makna, diantaranya etika merupakan suatu sistem nilai yang menjadi patokan seseorang melakukan

${ }^{21}$ Sudirin Sudirin, "Hubungan Antara Tokoh Masyarakat Dengan Moral Remaja di Desa Banjarrejo, Batanghari, Lampung Timur Tahun 2010," TAPIS: Jurnal Penelitian Ilmiah 11, no. 2 (2011): 157-173.

${ }^{22}$ Nur Aini Zulfa, "Pesan Akhlak Mahmudah Dan Madzmumah Dalam Buku Cerita Bergambar '99 Asmaul Husna Dan Kisah Para Princess'" (UIN Walisongo, 2016). 
sesuatu, moral merupakan suatu kebiasaan atau adat istiadat sedangkan akhlak itu sendiri merupakan sebuah sifat yang telah melekat dalam diri, sehingga akan muncul sesuai dengan keadaan hati. Pada intinya, akhlak, moral dan etika itu sendiri sangat berkaitan erat dan saling berhubungan, jika salah satu tidak dilakukan dan diterapkan dalam diri seseorang terutama peserta didik, maka yang akan terjadi adalah pelanggaran norma-norma yang berlaku.

Akhlak yang akan dibahas disini yakni sebuah akhlak mahmudah, dan memiliki sebuah sifat-sifat diantaranya: Taubat, Zuhud, Taqwa, Mahabbah, Sabar, Syukur, Ikhlas, Tawakal, Ridho, Mnegingat Mati dan hidup dengan disiplin. Itulah tadi merupakan sifat-sifat yang menunjukkan sebuah akhlak mahmudah, yang mana dalam menentukan akhlak mahmudah dapat dilihat dari ketingkatan iman yang dimiliki seseorang. Apabila iman seseorang itu baik, maka pengamalan akhlak mahmudah akan terlahirkan. Karena akhlak mahmudah akan terlahir dari kondisi iman yang baik, dan jika iman sedang tidak dalam kondisi baik yang akan terlahir adalah akhlak mazmumah.

\section{Model Pembelajaran Bandongan Pada Mata Pelajaran Akidah Akhlak}

Model pembelajaran merupakan sebuah gaya mengajar yang akan dilakukan atau bisa disebut sebagai prosedur yang digunakan untuk mengorganisasikan sebuah pengalaman belajar untuk mencapai tujuan yang diinginkan. Sebenarnya, model pembelajaran adalah wujud sari sebuah metode, strategi dan juga pendekatan. Wujud nyata dari sebuah strategi atau metode yang dilakukan akan menghasilkan sebuah model pembelajaran yang diharapkan bisa menghasilkan motivasi belajar peserta didik yang semangat. Metode disimpulkan sebagai sebuah cara yang akan dipergunakan untuk mencapai suatu tujuan pembelajaran agar tercapai sesuai dengan keinginan pendidik.
Kali ini, penulis akan menggunakan sebuah metode bandongan yang mana sudah sedikit dijelaskan di atas, yakni bandonganini merupakan sebuah metode yang digunakan untuk menjelaskan suatu mata pelajaran baik di sekolah maupun di madrasah. Yang lebih menonjol dari metode ini sering digunakan di pondok pesantren dan madrasah, karena metode ini menggunakan sekelompok orang, kemudian guru atau pendidik berada diantara mereka untuk menyampaikan materi, sedangkan mereka duduk melingkar disekitar guru dengan posisi siap menerima penejelasan dari ustadz, guru atau pendidik. ${ }^{23}$ Di Jawa, model pembelajaran ini disebut bandongan, sedangkan di beberapa daerah lainnya disebut dengan halaqoh. Setiap siswa yang sudah berkumpul disekitar guru, sudah membawa perlengakapan belajar, dan siap menerima materi yang guru sampaikan. Jika mengikuti model pembelajaran yang sesungguhnya seperti yang diterapkan pada pondok pesantren yakni dengan cara kyai duduk dikelilingi oleh santri-santrinya, kemudian santri sudah siap untuk mendapatkan ilmu dari sang kyai. Kyai tersebut membacakan kitab atau bukunya, dan santri menyimak kemudian mencatat apa yang mereka pahami dari yang disampaikan oleh kyai.

Dalam hal ini, guru menyampaikan dan menjelaskan materi dan mereka mencatat sesuai dengan apa yang telah mereka dengar ke dalam buku mereka. Kelompok dari metode bandongan sering disebut dengan halaqoh yang berarti lingkaran siswa atau sekelompok siswa yang sedang belajar dengan gurunya.Pada metode ini, siswa dituntut untuk konsentrasi terhadap apa yang disampaikan guru, dan siswa mencatat kedalam bukunya masing-masing untuk dijadikan sebagai bukti agar nantinya bisa dibaca setelah guru menjelaskan.

23 "Zamakhsyari Dhofier, Tradisi Pesantren: Studi Pandangan Hidup Kyai Dan Visinya Mengenai Masa Depan Indonesia, Jakarta : LP3ES, Cet. 9, Hlm. 54,pdf." 
Apabila peserta didik tidak konsentrasi dan teliti terhadap apa yang disampaikan guru, maka ia akan tertinggal dari apa yang dijelaskan oleh sang guru. Dan hal ini sangat cocok dengan materi pembentukan akhlak mahmudah yang penulis ambil. Karena metode ini menggunakan sistem pendekatan yang disengaja, untuk mengetahui kepribadian siswa tersebut. Metode ini tidak terikat dengan sebuah kurikulum, akan tetapi lebih kepada hanya menerapkan kebiasaan memisahkan antara santri laki-laki dan perempuan. ${ }^{24}$ Metode bandongan ini merupakan metode klasik yang digunakan masih di tempat-tempat yang sangat tradisional. Biasanya, metode ini sering diterapkan pada pesantren, langgarlanggar, atau rumah kyai itu sendiri.

\section{Kekurangan dan Kelebihan}

Modelpembelajaranbandonganyang sudah penulis jelaskan sedikit di atas, ada kesimpulan mengenai metode pembelajaran bandongan yang diterapkan dalam mata pelajaran akidah akhlak. Pembahasan diatas sudah pasti terdapat kekurangan dan juga kelebihan yang terdapat di dalam penerapan metode bandongan tersebut. Pada artiannya, setiap implementasi sebuah model pembelajaran jika dievaluasi akan terdapat suatu kekurangan dan juga kelebihan. Begitupun, dalam pembahasan metode bandongan ini, jika ditarik benang merah akan ada beberapa yang akan menjadi sebuah kekurangan dan juga kelebihan.

Semua yang dilihat belum tentu sempurna dan juga yang dilakukan tidak selalu totalitas, diantaranya yang menjadi sebuah kekurangan yaitu (1) model pembelajarannya terlalu sederhanajika masih diterapkan pada saat-saat seperti ini, dan manimbulkan kebosanan (2) peserta didik atau santri akan mudah mengantuk karena beberapa hal yang terjadi seperti munculnya rasa bosa dan lainnya (3) suara ustadz atau

24 "Aldy Mirza Fahmy.pdf." ustadzah yang menerangkan mata pelajaran yang kecil akan mengakibatkan peserta didik tidak memperhatikan secara masif tentang penjelasan ustadz atau ustadzah. (4) dalam metode ini, proses belajarnya yang monolog yakni alurnya lurus. (5) kurang diminati oleh siswa yang cerdas, karena sistem belajarnya yang diulang-ulang, seakan-akan tidak menambah wawasan lainnya. Adapun kelebihannya yaitu (1) peserta didik akan lebih aktif jika diajak untuk berdiskusi singkat oleh sang guru atau ustadz, karena lingkupnya yang memang akan dipergunakan untuk berdiskusi karena hanya berjumlah beberapa orang saja. (2) kemampuan yang dimiliki peserta didik atau santri akan terlihat disaat menggunakan metode ini, karena mana yang reaktif juga akan terlihat jelas. Alasannya, karena pada saat diskusi peserta didik atau santri yang sering bicara dan tidak akan nampak (3) tempatnya yang digunakan biasanya akan memudahkan peserta didik lebih berkonsentrasi dalam menerima pembelajaran, karena pada dasarnya metode bandongan akan lebih cenderung fokus belajar pada posisi yang nyaman. (4) lebih efektif dan juga praktis untuk mengajar siswa yang banyak. (5) materi akan mudah dipahami, dikarenakan selau diulang beberapa pertemuanyang lalu.

\section{Daftar Pustaka}

"aldy mirza fahmy.pdf," n.d.

Al-Ghazali. Ihya Ulumuddin,, n.d.

Djazimi, M. A. "pengaruh kecerdasan emosional terhadap akhlak siswa madrasah aliyahal-khairiyah provinsi banten." Studia Didaktika 10, no. 02 (2017): 48-64.

Haryanto, Haryanto. "Upaya Meningkatkan Etika Pergaulan Siswa Dengan Metode Demontrasi Mata Pelajaran Agidah Akhlak Materi Akhlak Mahmudah Kelas IV Semester I Di MI Karangwotan 
Pucakwangi Pati Tahun Periode 20102011." IAIN Walisongo, 2011.

Islam, Lembaga Studi, Kemasyarakatan (Jakarta, Indonesia), and others. Sejarah Pendidikan Islam

Di Indonesia: Lintasan Sejarah Pertumbuhan Dan Perkembangan. RajaGrafindo Persada, 1995.

Lampiran Peraturan Menteri Agama Republik Indonesia Nomor 2 Tahun 2008 Tentang Standar Kompetensi Lulusan Dan Standar Isi Pendidikan Agama Islam., n.d. http://sutardicool.files. wordpress.com/2013/02/permenagno-8-tahun-2008-ttg-standar-isi-ktsp. pdf.

Marzuki. Prinsip Dasar Akhlak Mulia,. Yogyakarta, Debut Wahana Pers, 2009.

Nasution, Nurseri Hasnah. "metode dakwah dalam membentuk akhlak mahmudah remaja."Wardah 12, no. 2 (2015): 163- 177.

Nikmaturrohmah, Imroatul Latif. "Pembiasaan Shalat Dhuha Dalam Pembinaan Akhlak Peserta Didik Di MTs Al-Ghozali Panjerejo Rejotangan Tulungagung" (2014).

Pembagian Akhlak Dalam Islam,. Andi Pramudya,. (http://konsep-islam. blogspot.com/2011/10/pembagianakhlak-dalam-islam.html), 2011.

Rahayu, Puji. "Peran Dakwah Muslimat Nahdlatul Ulama Dalam Pembinaan Akhlak Warga Desa Bendar Kecamatan Juwana Kabupaten Pati." IAIN Walisongo, 2013. http://eprints. walisongo.ac.id/1920/.

Sudirin, Sudirin. "hubungan antara tokoh masyarakat dengan moral remaja di desa banjarrejo, batanghari, lampung timur tahun 2010." TAPIS: Jurnal Penelitian Ilmiah 11, no. 2 (2011): 157-173.

Tabrani Yusran. Pendekatan Pada Proses Belajar
Mengajar. Bandung: PT Remaja Rosdakarya, n.d.

Yuniarti, Tri, and Syamsu Hadi. "Peningkatan Kemampuan Analisis Pokok Bahasan Masalah Ekonomi Dengan Model Pembelajaran Problem Based Learning (PBL) Siswa SMA Negeri 1 Bandongan Kabupaten Magelang." Dinamika Pendidikan 10, no. 1 (2015): 76-87.

“Zamakhsyari Dhofier, Tradisi Pesantren: Studi Pandangan Hidup Kyai Dan Visinya Mengenai Masa Depan Indonesia, Jakarta: LP3ES, Cet. 9, Hlm. 54."Jakarta : LP3ES. cet. 9, hlm. 54. (n.d.).

Zubaidi, Muhammad Addib, and others. 'Sistem Pendidikan Dakwah Pondok Pesantren Nurul Haromain Pujon Malang Dan Perkembangannya.Skripsi, Universitas Negeri Malang Fakultas Ilmu Sosial, Malang, 2012. http:// jurnalonline.um.ac.id/data/artikel/7E 1416A3E9F21E892782EA3215B47D8 D.pdf.

Zulfa, Nur Aini. "Pesan Akhlak Mahmudah Dan Madzmumah Dalam Buku Cerita Bergambar'99 Asmaul Husna Dan Kisah Para Princess'." UIN Walisongo, 2016. 